\title{
Learning Improvement of Wood Carving Skills in SMK for Preservation of Local Wisdom and Its Contribution in Furniture Industrial Sector in Jepara
}

\author{
Muh Fakhrihun Na'am ${ }^{1}$, Taofan Ali Achmadi ${ }^{1}$, and Qori Zakiyyatussa'diyyah ${ }^{1}$ \\ ${ }^{1}$ Department of Home Economics, Semarang State University, Semarang, Indonesia \\ fakhri.artworker@mail.unnes.ac.id,taofanali@mail.unnes.ac.id,qorijklmn@gmail.com
}

Keywords: Jepara's woodcarving, Vocational High School, Local wisdom

Abstract: Jepara wood carving is one of the riches of ancestral cultural heritage in the past, creating various types and distinctive carved ornaments as Jepara local wisdom. The structure of wood carving as an art form is sometimes juxtaposed with visual language, which is when someone learns to understand and learn how each element is arranged together. The parts and objectives of woodcarving as the language have their own meanings and important to learn for science. The organization of visual elements in woodcarving is called formal values or syntactic values and raises an additional source of satisfaction and pleasure. From this case, the study of the elements of woodcarving and organizing ornaments is an attempt to describe the public's attention to sources that rise to pleasure, aesthetic meaning, and the functions. Jepara's woodcarving instills a cultural understanding, and as a reference in achieving science, economic growth, and art to create a smart society. In connection with this matter, Vocational School as a place to learn skills is very appropriate as a medium and a means to realize these goals, accompanied by supporting and relevant research. The research uses a literature study, observation, documentation, interviews, experiment methods. The stages of woodcarving preservation are embodiment process, an inventory of existing Jepara`s wood carvings, and then analyzing the data; inventory of batik, craftsmen, artists, woodcarvings that have acquired copyright and industrial areas.

\section{INTRODUCTION}

Jepara is an area located on the Java island that has a very long historical track record. Jepara also proved to be the color of Indonesia's national cultural history. One of the vestige that is still rather vague is the existence of the Kingdom of Kalingga in the VIIX century. Even though the location of the kingdom is still being debated by the historians, some people believe that in the sixth century, the kingdom of Holing was estimated to have existed in Jepara. This kingdom was told as a producer of gold, silver, horns, turtles, and ivory. The queen lives in a palace which roof is made of sago palm leaves and her throne is made of carved elephant ivory. Generally, the houses in Kalingga have roofs made of sago palm leaves, but some household furniture and utensils are have been made by wood. While the livelihoods of Kalingga residents are farming, mining, trading, fishing, and hunting. They also began to know how to make boats (Hadi Priyanto, 2013: 1-2). Ka-ling or Kalingga, is a term of a Hindu state originating from the east coast of India. Another story explain that Ka-Ling is a word used in Javanese literature, meaning foreigners. This shows the connection between the kingdom of Kalingga and foreigners or immigrants from the kingdom of Kaling in India. This linkage is very possible due to the development of the field of commerce due to the emergence of political chaos (SP. Gustami, 2000: 82).

The kingdom of Kalingga was led by Queen Shima, Queen Shima ruled her kingdom fairly and wisely. The failure and wisdom can be seen in her obedience of upholding the laws and regulations stipulated by the kingdom, so that the taken decisions do not cause doubt in the implementation. That is why the Queen Shima is respected not only by her own people but also by other nations. King Ta-che, the king of Arabia heard the wisdom and justice of Queen Shima, he sent a commander to put 
coffers containing dinars in the middle of the road. It was stated, that for three years, those who passed by no one dared to pick up the coffers. When the crown prince took a walk, his feet accidentally touched the coffers. Because of his mistake, Queen Shima warned that the crown prince was sentenced to beheading. Based on the consideration of the legal expert and the royal authorities, finally, the crown prince's leg was amputated as the law, because his leg was the one who was guilty. After hearing that, King Ta-che felt reluctant and did not dare to attack Queen Shima (SP. Gustami, 2000: 84-85).

There is a district in Jepara which is the hometown of R. A. Kartini, this region is located on the northern tip of Java, Central Java Province. Jepara is better known as the town of carving. The nature and the environment in Jepara have a special attraction for anyone who sees it. Jepara has an attractive coastal, various of arts, historical places such as R.A Kartini museum, Portuguese Fort, Mantingan Mosque and Tomb of Sultan Hadlirin which is located in Mantingan village, Jepara. Jepara is a Level 11 district in Central Java Province, which is the northern coastal region of Java. In addition to producing woodcarvings, Jepara is also known as a traditional weaving town, known as Troso weaving.

Thus far, Jepara is known as a historical town. This town has many female personages, such as Queen Shima, Queen Kalinyamat, and R.A Kartini. The introduction of of jepara wood carving local wisdom can be an innovative step to find alternative learning media. The culture possessed by a district area is a necessity. Creating a relevant and interesting communication media will increase the economic aspects of the surrounding community and contribute to the tourism sector, develop wood carving works and develop the furniture industry.

The communities around Jepara continue to develop dynamically. this is visible in the growth of wood carving. Changes in form, function, and meaning of wood carving are influenced by the view of life of the supporting community in addition to the influence from the outside culture. At least there are four things that influence the acculturation process, namely: language; technology, especially architecture; religion; and art, including sculpture, building art, decorative arts, literary art, and performing arts (Koentjaraningrat, 1986: 82-84). Jepara wood carving is inseparable from the role of R.A Kartini, for example, evidence that R.A Kartini held a wood carving exhibition. The existence of Vocational Schools in Jepara is very appropriate to develop wood carving with a long-term orientation considering young students are very important to cultivate the values of having ancestral expertise as local wisdom which is expected to continue to grow and develop. Vocational schools in Jepara especially the woodcraft art field in woodcraft. Vocational high schools that are actually formal schools are the basis and place to forge relevant young people. Besides being able to continue at the tertiary level with vocational education as a proper consideration, also after graduating from Vocational School, they can immediately work where there are very many companies and centers in the woodcraft industry.

Reference efforts for the preservation and development of wood carving include the synergy between Vocational Schools as formal education with companies in the region, artists, designers, private institutions, and government agencies. The education sector in Indonesia is currently becoming a concern of the government. Because, as a country with a population reaching 250 million people, it is expected that the Indonesian education sector can create a workforce that is independent, reliable, and competitive, especially in the industrial sector. This is necessary because along with technological developments and free markets in various regions, labor competency factors are the main thing in maintaining economic competitiveness. For this reason, the government is now starting a vocational education program for Vocational Schools (Vocational Schools), vocational education is rolled out so that the education system is in line with needs.

(SMK) plays a positive role in regional economic growth. This role can be traced from three things that are mutually sequential, namely: (1) people's preference for vocational schools, (2) vocational capacity for junior high school graduates, and (3) vocational ability in producing quality graduates. The public's interest in SMK is related to the development of vocational schools, and the development of SMK is related to the quality of graduates. This quality becomes a determinant in the labor market, and in turn, contributes to regional economic growth. The more qualified the vocational school graduates, the easier it will be to absorb in the labor market. Successfully becoming a worker in the labor market means creating income.

The absorption of vocational knowledge in the labor market means the creation of income for SMK alumni, as well as income for the region (in the form of GRDP) where the alumni work. In order to develop vocational schools in the future, this study underlines how vocational schools are between forces borrowed Porter's term (1979), namely a junior high school market where vocational "buy" 
inputs and labor markets where SMK "sells" its output. This means various determinants (such as school fees, school facilities, socio-economic background of junior high school graduate parents) which explain why junior high school graduates choose (or do not choose) SMK, need to be considered. On the other hand, the desire of DUDI in the region (which is in the labor market) must also be considered. For example, areas that are "concentrated" with workers in the mining sector, of course, desperately need graduates with degrees in mining. It is fairer for the next study to map junior high school graduates' preferences towards Vocational Schools on the one hand and DUDI preferences on the other. Of course all of this in order to further strengthen the SMK steps in contributing to regional economic growth.

\section{METHOD}

For the mutual benefit and protection of Authors and Publishers, it is necessary that Authors provide formal written Consent to Publish and Transfer of Copyright before the publication of the Book. The signed Consent ensures that the publisher has the Author's authorization to publish the Contribution. The copyright form is located on the authors' reserved area.

The form should be completed and signed by one author on behalf of all the other authors.

\section{RESULT AND DISCUSSION}

Vocational High Schools (SMKs) are mandated by law to prepare human resources who are ready to enter the workforce and become a productive workforce. Vocational graduates are ideally ready to use labor, in the sense that they can directly work in the business world and industry. Vocational School is a place of learning especially in the field of skills that has the contents of practical learning theory. Situated Learning is a learning theory that studies the acquisition of knowledge and skills used in the world of work (Brown, 1998). Stein (1998: 1) identifies four principles related to situated learning, namely: (1) learning is rooted in everyday cognition, (2) knowledge is obtained situationally and transfers take place only in similar situations (context), and learning is the result of social processes that include ways of thinking, looking at things, solving problems, and interacting in addition to declarative and procedural knowledge, and (4) learning is something that is not separate from the world of action but exists in a healthy social environment and complex that increases actors, actions, and situations. Of these four principles, the second principle is an environment similar to the world of work that is actually needed by schools. The environment of the business world and the industrial world is a learning environment that provides the experience of students who support work in industry is their own industry. Work-Based Learning (WBL) is a form of contextual learning where the learning process is centered on the workplace and includes a planned program of formal training and mentoring and the search for salaried work experience. Raelin (2008: 2) states that WBL expressively combines theory with practice, knowledge with. WBL recognizes that workplaces offer many opportunities for learning as in the classroom. The internship system is one form of WBL. In this system, students learn with an expert or maestro through observation and imitation of behavior and how it works intensely so they can get specific experience. The existing learning theories cannot be separated from the subject matter, in this case, is wood carving which cannot be separated from its historical background. The history of own wood carving in Jepara can be explored, one of which is the bleak event of the Majapahit Kingdom, the more gloomy also the classical carving art. Instead, a pattern of carving was developed which was influenced by the civilization of Islamic culture. When Majapahit collapsed, it was estimated that many artists carved into the Sultanate of Demak, which later developed as an Islamic center on the island of Java at that time. Because of the many artists carving from Majapahit who migrated to Demak, the Sultan of Cirebon asked the Sultan of Demak so that some artists from Majapahit could help complete the construction of the tomb of Sunan Gunung Jati in Cirebon. The request of the Sultan of Cirebon was passed by the Sultan of Demak by sending a number of reliable artists. The artists from Majapahit then did not only live in Demak, but also later developed Kudus and Jepara carving arts. They not only make carved furniture but also carved the furniture and traditional houses (Hadi Priyanto, et al., 2013: 18).

Jepara is rich in artifacts when viewed from the facts of the existing historical heritage, expertise heritage, artifacts, and ruins that are still being treated. One of the legacies of artifacts is ornaments at the Mosque complex and Mantingan Tomb. As one of the cultural heritages, ornaments at the Mosque and Mantingan Tomb should be studied in depth. This historic artifact is located five kilometers south of downtown Jepara, namely in the village of 
Mantingan. The mosque and tomb are relics of early Islam on Java and become one of the historical tourism assets in Jepara. In this place stands a magnificent mosque built by Queen Kalinyamat. Mantingan Mosque, which was used as the center for the spread of Islam on the north coast of Java, was the second mosque built in Java after the Great Mosque of Demak. This activity is the beginning of Islam on the island of Java. Mantingan Mosque is similar to mosques in other port cities in the 15 th and 16th centuries. Mosques and places of religious education are independent and sometimes located deep in the mountains as the center of Islamic religious activities (Graaf, H.J, 1985: 52).

The Mosque Complex and Mantingan Tomb are located in a higher place compared to the condition of the surrounding land (hills) which is considered a place of honor. This placement was influenced by pre-Hindu thinking which believed that the ancestors lived in trees, hills, and mountains. The gods and powerful figures are also believed to live in the highlands. This belief can be interpreted that a person must respect his ancestors. The figure of a deceased ancestor is believed to continue to protect and protect the lives of his offspring from high places (Ajatrohaedi, 1970: 34).

In the building in the mosque complex and Mantingan Tomb, there is a rounded fence that has been cemented whose function is intended to better tidy up the building. The complex consists of two core buildings namely the Mosque and the Tomb. Mantingan Mosque was built in 1748 Saka or 1559 $\mathrm{AD}$ based on the instructions from condro sengkolo engraved on a mihrab Mantingan Mosque reads "Rupo Brahmana Sari Color which means Fine $=8$, Brahmana $=4$, Color $=7$ and Sari $=1 "$ so if read reversed to the number 1748 (Harjono, 2009: 9-10).

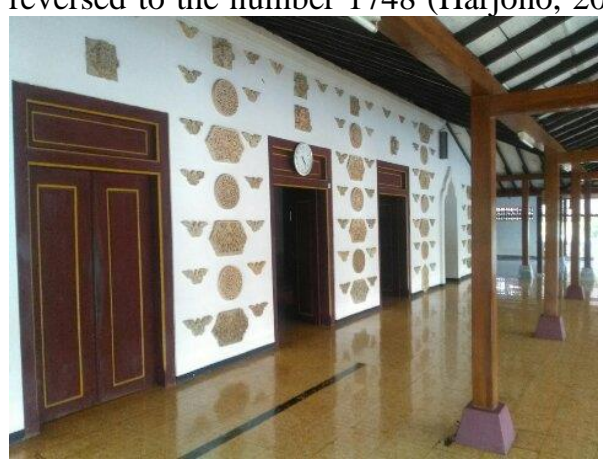

Figure 1. Ornaments on the Wall of the Mantingan Mosque

In the creation of ornaments can choose a form or several to be used as a motif. The motifs have original forms that are diverse and contain beauty. However, the shape and beauty are not necessarily ready to use to be applied in the decorative field that we want. To overcome this, we need to stylize the motives first, which means changing the original shape to get a beautiful new shape that is in accordance with the ornamental fields we provide. Thus the hope of obtaining ornamental new forms. The stylization results are then arranged regularly in the ornamental field. Ordering in this arrangement is necessary to get results that are calm and pleasing to the eye. This result is called "ornament" (D. Dalidjo Mulyadi, 1983: 77-78).

Jepara ornaments are stiliran of creeping plant forms. Therefore, the main leaf ornament of Jepara is in the form of a niche. The stems are circular, branched, connected to function to fill space. Each end of the niche is a form of very dynamic krawing leaf tufts. The cross-section of the niche and the ornamental leaves of Jepara are made in the form of triangles and in the middle of the tassels there are small round fruit shaped Jepara ornaments are also often combined with peacock motifs. While Jepara ornament elements include niches like Pajajaran ornaments with staple leaves shaped like a coil but the shape is rather open so it gives a strong impression. While angkup lay flat on the top of the main leaf and on the lower part of the stem of angkup it grows trubusan. Endhong in Jepara ornaments is a leaf that grows in layers behind the main leaf from the bottom to the top and the form of the line is rather thick in the form of an embossed and slightly sloping. Benangan is on the front of the main leaf from the bottom to the top and stops at the main thread. The cymbals in Jepara ornaments are in the form of small leaves that grow in line from the bottom up and stick to the threads. As for the line fragments and cawen, it functions as a sweetener which adds to the flexibility of Jepara ornaments.

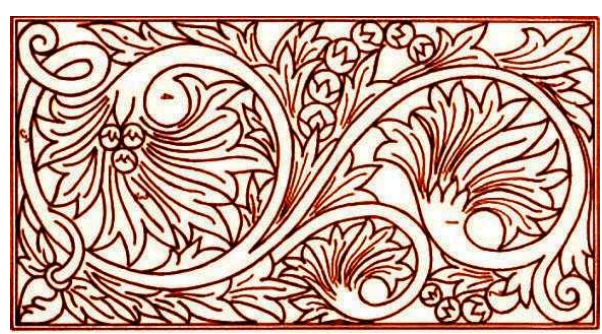

Figure. 2 Jepara Ornaments 


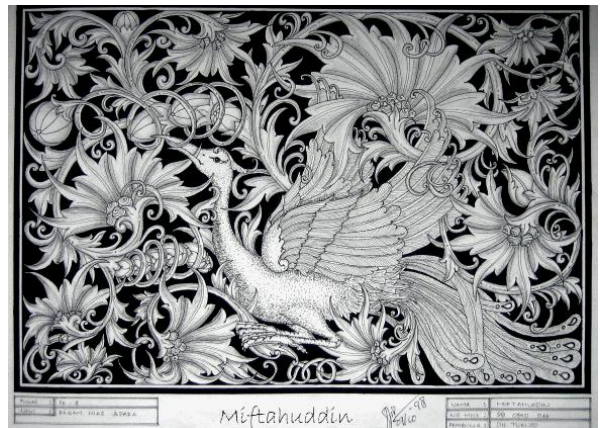

Figure 3. Jepara ornaments combined with fauna elements

Principal: From the Jepara ornament the outline is a circular prism that is circular and from the end of the circle it breaks into several leaves, leading to a circle of handles or principal and mutating in rhythm with that variety. Fruit: is in the meeting corner of the circle, in the form of small rounds arranged like a wuni. Fractions: is chrism shaped like a ray of a leaf. Weakness: It is the basis, in practice, it is not so in that there are also those who are blinded or translucent.

In the development of the creation of works of art including Jepara carving in it can take the concept of cultural strategy, namely in the history of mankind a work of art takes place in the process of manifestation can be distinguished by several factors, but the priority here is the scheme, a three explanation that highlights its main characteristics. The three stages in this section are mystical stages, ontological stages, and functional stages. the mystical stage which is intended is the attitude of humans who feel themselves surrounded by the surrounding magical powers, namely the power of the gods of the universe or the power of fertility, as staged in mythologies called primitive nations. Even in modern culture, this mystical attitude is still felt. The ontological stage is the attitude of humans who do not live anymore in the siege of mystical power, but who freely want to examine all matters. The human takes distance from everything first felt like a siege. He began to compile a teaching or theory about the basic nature of everything (ontology) and about everything according to its details (sciences). We will see that the ontology developed in the environments of ancient cultures which were greatly influenced by nature and science. The third stage is functional is the attitude and the mind that is increasingly visible in modern humans. He was not so fascinated by his environment (mystical attitude). $\mathrm{He}$ is no longer with a cold head distance from the object of his investigation (ontological attitude). No, he wants to hold new relationships, a new link to everything in his environment (Van Peursen, 1988: 18-19).

Jepara Carving as Jepara local wisdom is manifested into the realm of the creative industry. These development efforts besides contributing positively to the economy, art, culture, innovation, and learning, as well as the introduction to other regions, so tourism is also elevated. This development innovation should make the motivation of other craftsmen so that the massive movement for regional and national interests. The creative industry from existing local wisdom is indeed intensively implemented, this happens massively in almost all parts of Indonesia. This indicates that the creativity of the people in each region does occur simultaneously with the influence of the potential of human resources, both the teaching profession, craftsmen, artists, and business people. The motivation for the creation of works based on local wisdom is indeed diverse but it is more dominated by economic factors. Apart from any factors that influence the creative wisdom-based industry, it should be fully appreciated.

Creative industries are business activities that focus on creation and innovation. The creative industry is still potential to work on, and Indonesia is rich in culture and traditions that can be a source of creativity, including Jepara wood carving as mentioned above. The national creative industry actors must be masters in their own country and continue to develop the domestic share of even the export market. Moreover, cultural wealth-based creativity is also supported by technological advances. The diverse and varied cultural wealth is a source of inspiration and its potential is even greater when supported by technology. The use of technology for marketing, for example, is very significant for wood carving products, the use of information technology, social media, and online marketing is a necessity in the era of the current era. Creative industry products will develop if supported by the domestic market. In this case, it is important for producers to strengthen their position in the country even though their work abroad also continues to increase.

Domestic consumers also need to provide support with their love of domestic products. This will support the ability of creative industries to be masters in their own country.

In Indonesia, including in the Jepara region, the creative industry is developing rapidly, experts and economists argue that the income of the state is partly contributed by the creative industry which 
continues to grow and develop at any time. The creative industry itself is an industry that originates from utilizing the activities, skills, and talents of individuals to create prosperity and employment by generating and exploiting the individual's creative and creative power. The creative industry currently has a very important role in the economy of a country, not only in developing countries like Indonesia. This cannot be separated because the creative industry has a role to improve the economy of a country globally. The creative industry is closely connected with the level of human creativity as the main resource for driving the economy. The number of creative industries created is as a fruit of creativity and innovation developed by someone.

Entering the digital era, the opportunity of the creative industry seems to find a bright spot. The amount of public attention to something different, unique and interesting, of course, becomes a separate segmentation. The concept of the creative industry itself is a new business that intensifies information and creativity by relying on ideas and knowledge from human resources as the main factors driving the economy. In short, this business emphasizes creativity, ideas, innovation, from human resources in presenting domestic products and can open up competitive product markets that can compete internationally. It can be said that human creativity is the main economic resource and industry that is increasingly developing today depending on the production of knowledge through creativity and innovation.

Thus the creative industry is an industrial sector originating from the utilization of creativity, skills, and individual talents to create prosperity and employment through the creation and utilization of individual creative power, skills, and talents that have the potential of wealth and the creation of employment opportunities through the exploitation of intellectual property to achieve the emergence of individual and community welfare in order to increase national economic growth. One of the important breakthroughs to raise the economy of the Indonesian people and to meet domestic consumption needs and increase exports is how to develop and create a creative industry that can open business opportunities and labor in the surrounding community. Because basically the creative industry is an industrial sector that comes from the utilization of creativity, skills, and individual talents to create prosperity and employment through the creation and utilization of individual creativity, skills, and talents that have the potential for wealth and the creation of employment opportunities.
Challenges in the creative industry can be seen in two scopes of study, namely the scope of economic studies and the scope of creative studies. The main challenge that is most likely to be a question and debate is the shifting of the meaning of creativity with higher values in terms of art as cultural arts. On the other hand, works of art will be products that sell goods or services in the art and culture market, without further considering the artistic aspects of the artwork. The creative industry or cultural industry is the activity concerned with the production and marketing of goods and services that have aesthetic content. Various studies have revealed, the emergence of creative industries as the engine of economic growth reflects the economic and cultural conjunctions in which commodity production has become tied to artistic experiments that produce latent tensions between art and commercial considerations.

In addition to efforts to develop through information technology as mentioned above, other significant efforts, for example, are to create groups based on professions where the profession has not had the chance to create wood carving to the fullest because of their busy life. Set aside time after routine activities can be done, namely carving after teaching for the teaching profession, carving after returning from the company or other leisure time. After producing the work the group conducts regular meetings and holds scheduled exhibitions that can be weekly or monthly while discussing and publicizing. The next effort is to encourage the world of academics where students, teachers, and lecturers can write scientific works on ideas and ideas about Jepara carving from various aspects. Encouraging relevant agencies, both private and government, to implement programs that are significantly and positively contributing to the development of Jepara carving.

\section{CONCLUSIONS}

Vocational High School Education (SMK) as a secondary level vocational education has a big role in planning and creating professional and productive HR. Education in Vocational High Schools (SMK) aims to increase students' knowledge and skills in order to prepare them to become a middle-level workforce. Vocational High Schools (SMK) as one of the educational institutions that have a mission to prepare middle-level workers who are able to fill jobs and professional quality are expected to be able to play a leading tool for Indonesian industries in 
facing global competition. Vocational education is also an investment to improve the quality of human resources, which is the main requirement for increasing the rate of economic growth, equal opportunity, and social change. Education and training is an effort to develop human resources, especially for the development of intellectual abilities and human personality. Formal education in an organization is a process of developing capabilities towards those desired by the organization concerned, while training is part of an educational process whose purpose is to improve the abilities or special skills of a person or group of people. In accordance with the objectives of the Vocational School, it is one of the institutions that prepare workers.

The workforce here is the field of Jepara wood carving which is a work of art inherited from the ancestors with all the efforts of our ancestors trying to provide an artistic heritage that deserves to be preserved and developed. Social, economic and cultural factors have accompanied the journey and continuity of Jepara carving. Evidence of artifacts and history proves that our ancestors are great people who want to pass on expertise in the field of art which in addition can be enjoyed visually also contributes positively to the growth of the economy, as identity and tourism in the present.

The Jepara area is an area full of artistic and industrial potential, as a carving town. The existence of the furniture industry, which consists of Jepara ornaments found in wood carving, with the potential of human resources, is now the hope with all the efforts of Jepara wood carving that has been faced with other emerging industries, problems of raw materials, competition, labor, and Information Technology. The development of wood carving must be addressed intelligently and always dynamically according to the development of the times without eliminating the artistic values contained in it. Efforts should be made to form a community to create wood carvings in a scheduled, focused, measurable, and directed manner.

Creative industry players in Jepara must be masters in their own regions and continue to develop export market shares. Moreover, local wisdom-based creativity is also supported by advances in technology and information. The diverse and varied cultural wealth is a source of inspiration and its potential is even greater when supported by technology and information. To develop the creative industry collaboration is needed to strengthen between institutions, craftsmen, and the government. The creative industry from the local wisdom of carving Jepara wood and local trade in the market shows that there is economic independence that is part of the life of the Jepara community. The presence of creativity, economic diversification, and trade activities shows that the Jepara community still inherits economic traditions that are more open, creative and cosmopolitan. In the end, cooperation between institutions, academics, private institutions, and the government was required to support each other in activities that contributed positively to the sustainability of the Jepara carving industry. These activities for example by carrying out exhibitions, seminars, and scientific publications.

\section{REFERENCES}

Ajatrohaedi. (1970). Gunung Dalam Kebudayaan Tempat Dewa-Dewa, Nenek dan Orang-Orang Sakti Bersemayam. Majalah Djogja 8 Februari 1970.

Brown, L. B. (1998). Applyng Constructivism in Vocational and Career Education. Columbus: ERIC.

Feldman, Edmund Burke. (1967). Art As Image and Idea. New Jersey: Prentice-Hall, Inc.

Feldman, Edmund Burke. (1991). Art As Image and Idea. New Jersey: Prentice-Hall, Inc.

Gustami, S.P. (2000). Seni Kerajinan Mebel Ukir Jepara, Kajian Etetika Melalui Pendekatan Multidispliner. Yogyakarta: Penerbit Kanisius.

Graaf, H.J. (1985). Kerajaan-Kerajaan Islam di Jawa: Peralihan dari Majapahit ke Mataram (Grafitipers dan KITLV, Translate). Jakarta: Grafitipers.

Koentjaraningrat. (1986). Peran Lokal Genius dalam Alkulturasi, dalam Ayatrohaedi, Kepribadian Budaya Bangsa. Jakarta: Pustaka Jaya.

Munro, Thomas. (1969). The Art and Their Interrelations. London. London: The Press of Case Western Reserves University Clevelandand.

Mulyadi, D. Dalidjo. (1983). Pengenalan Ragam Hias Jawa 1a. Jakarta: Direktorat Menengah Kejuruan. Dirjen Dikdasmen.

Peursen, C.A.V. (1988). Strategi Kebudayaan. Yogyakarta: Penerbit Kanisius.

Priyanto, H., et el. (2013). Mozaik Seni Ukir Jepara. Jepara Lembaga Pelestari Seni Ukir, Batik, dan Tenun Jepara. Jepara: Pemerintah Kabupaten Jepara

Raelin, J.A. (2008). Work-Based Learning: Bridging knowledge and action in the worksplace. San Francisco: Jossey-Bass.

Sunaryo, Aryo. (2006). Ornamen Nusantara Kajian Khusus tentang Ornamen Indonesia. Semarang: Dahara Prize.

Trilling, James. (2001). The Language of Ornament. London: Thames \& Houdson Ltd 181A High Holborn. 